$$
\begin{array}{c|l}
\text { Jurnal Sains Komputer dan Teknologi lnformasi } & \text { Page } \\
\text { e-issn: 2655-7460. Volume i No.2, Mei 2019 } & \text { 20-26 }
\end{array}
$$

\title{
IMPLEMENTASI MEDIA PEMBELAJARAN BERBASIS MULTIMEDIA UNTUK MENINGKATKAN MINAT DAN MOTIVASI BELAJAR BAHASA INGGRIS PADA ANAK DI DESA PETUK KETIMPUN PROVINSI KALIMANTAN TENGAH
}

\author{
Norhayati ${ }^{1}$, Rosmiati ${ }^{2}$ \\ ${ }^{182)}$ Program Studi Sistem Informasi, STMIK Palangkaraya \\ Jalan George Obos, No 114, Palangkaraya, Kalimantan Tengah \\ Email: ${ }^{1)}$ inoynorhayati@gmail.com, ${ }^{2)}$ fayadhah@gmail.com
}

\begin{abstract}
ABSTRAK
Pemanfaatan teknologi dalam kehidupan sehari-hari telah terbukti dapat membantu mempermudah pekerjaan manusia. Begitu pula dalam bidang Pendidikan. Teknologi yang beragam telah mentranformasi bebrapa aspek dalam dunia Pendidikan. Salah satu aspek tersebut adalah media pembelajaran.

Ragam dan bentuk media pembelajaran yang beragam dapat mempengaruhi minat anak dalam mempelajari suatu bidang pelajaran. Pelajaran bahasa Inggris yang selalu lekat dengan penggunaan buku teks dan kamus dapan menjadi lebih variatif jika media pembelajaran yang digunakan mendapat sentuhan teknologi.

Penerapan aplikasi media pembelajaran berbasis multimedia bahasa Inggris yang telah dibuat dengan menggunakan metode MDLC (Mutimedia Development Life Cycle) diharapkan mampu memudahkan anak untuk belajar bahasa Inggris baik secara mandiri maupun didampingi oleh guru. Desa Petuk Ketimpun dipilih sebagai objek penelitian karena lokasinya yang berada dipinggiran kota Palangkaraya. Sehingga penelitian ini juga memiliki misi untuk memperkenalkan teknologi kepada anak-anak dan masyarakat didaerah tersebut.
\end{abstract}

Keyword : implementasi media ajar, bahasa Inggris, multimedia, young learner

\section{ABSTRACT}

The use of technology in daily life has proved to help facilitate human work. Similarly in the field of education. The diverse technology has transformed many aspects in the education world. One such aspect is the learning medium.

The variety and form of diverse learning media can affect the child's interest in learning a field of study. English lessons are always close to the use of textbooks and precipitation dictionaries become more varied if the learning media used gets a touch of technology.

The application of English multimedia based Learning media application that has been created using MDLC (Mutimedia Development Life Cycle) method is expected to facilitate children to learn English either independently or accompanied by By the teacher. The village of Petuk Ketimpun was chosen as a research object because of its location which is located in the city of Palangkaraya. So the research also has a mission to introduce technology to children and communities in the area.

\section{Keyword: Implementation of teaching Media, English, multimedia, young learner}

\section{PENDAHULUAN}

Proses pembelajaran bagi young learner yang diterapkan baik disekolah maupun lembaga Pendidikan lainnya lazimnya menggunakan media belajar konvensional, baik berupa; buku bergambar, flash card, realia dan sebagainya. Penggunaan media belajar yang konvensional memiliki beberapa kelemahan, salah satunya adalah keterbaharuan materi yang ada dalam media tersebut. Misalkan untuk buku bergambar, buku bergambar memiliki seri tersendiri terkait dengan topik yang ingin disampaikan melalui buku tersebut. Jika buku bergambar tersebut membahas mengenai hewan maka seluruh isi buku tersebut adalah tentang hewan. Apabila anak ingin mempelajari tentang topik yang lain, misalkan tumbuhan, maka anak tersebut harus menggunakan buku yang lain. Sementara itu dari segi harga, buku bergambar 
tidaklah cukup terjangkau bagi anak-anak yang tinggal di Desa Petuk Ketimpun.

Berkaitan dengan hal tersebut, maka peneliti tertarik untuk melakukan pemanfaatan teknologi untuk mempermudah kegiatan dalam belajar bahasa Inggris. Pemanfaatan ini berupa penggunakan teknologi untuk membuat media belajar yang dapat digunakan baik secara mandiri oleh anak maupun secara bersama-sama dikelas. Media pembelajaran yang mudah digunakan, menarik dan interaktif diharapkan dapat pula meningkatkan minat dan motivasi anak dalam belajar bahasa Inggris.

\section{METODE}

Model penelitian yang digunakan dalam penelitian ini adalah Penelitian dan Pengembangan atau Research and Development (R\&D). Penelitian dan pengembangan merupakan suatu proses atau langkah-langkah untuk mengembangkan sistem baru atau menyempurnakan sistem yang ada. Metode penelitian ini digunakan untuk meneliti apa saja yang diperlukan dalam penyampaian informasi dan mengembangkan penelitian tersebut dengan pembaruan sistem yang baru yang nantinya akan diterapkan.

Pemodelan yang digunakan tim peneliti adalah MDLC (Multimedia Development Life Cycle). Tahap-tahapnya adalah sebagai berikut:

1. Konsep (Concept)

Beberapa hal yang tim peneliti lakukan pada tahap konsep antara lain:

a. Merumuskan dasar-dasar dari bentuk media pembelajaran interaktif yang dibuat dan dikembangkan. Terutama pada tujuan dan jenis pelajaran yang akan dibuat.

b. Menentukan jenis media pembelajaran yang akan dibuat.

c. Menentukan sasaran penggunaan media pembelajaran.

Dari beberapa hal tersebut dapat diketahui bahwa jenis media pembelajaran yang akan dibuat adalah aplikasi yang bersifat interaktif. Tujuan pembuatan aplikasi ini adalah sebagai media pembelajaran bahasa Inggris berbasis multimedia untuk anak-anak .

\section{Desain (Design)}

Tahapan dimana bagian-bagian dari media pembelajaran tersebut disusun sedemikan rupa sehingga bisa memberikan gambaran nyata mengenai bentuk akhir dari media pembelajaran yang dibuat.

3. Pengumpulan Bahan (Material Collecting) Beberapa hal yang dilakukan dalam tahap ini adalah:

a. Mengumpulkan gambar yang berhubungan dengan pembelajaran anggota tubuh bagian luar dalam Bahasa Inggris.

b. Mengumpulkan file-file musik, suara, dan Video yang akan digunakan.

c. Mengumpulkan materi pembelajaran anggota tubuh bagian luar dalam Bahasa Inggris.

4. Pembuatan (Assembly)

Pada tahap Pembuatan (Assembly), materimateri serta file-file multimedia yang sudah didapat dirangkai dan disusun sesuai dengan desain. Pada proses pembuatan ini sangat diperlukan keterampilan yang kreatif agar mendapat hasil yang baik. Pembuatan aplikasi media pembelajaran bahasa Inggris berbasis multimedia menggunakan aplikasi Adobe Flash Professional CS6.

5. Pengujian (Testing)

Pada tahap ini, aplikasi yang telah dibuat di uji coba untuk melihat apakah aplikasi yang dibuat sudah sesuai dengan yang diinginkan atau masih ada yang harus diperbaiki.

6. Distribusi (Distribution)

Pada tahap ini, tim peneliti melakukan distribusi aplikasi kepada pengguna (pengguna). Pendistribusian aplikasi ini juga bertujuan untuk mengevaluasi apakah aplikasi yang digunakan dapat dioperasikan oleh pengguna atau tidak.

\section{Teknik dan Alat Bantu Analisis}

a. UML (Unified Modeling Language) UML (Unified Modeling Language) terdiri atas pengelompokan diagram-diagram sistem menurut aspek atau sudut pandang tertentu. Diagram adalah yang menggambarkan permasalahan maupun solusi dari permasalahan suatu model.

b. Use Case Diagram

Di dalam Menu Utama, pengguna dapat mengakses beberapa menu, seperti: About, Instruction, Copyright, Home, Play, Learning Activity, Head Parts, Body Parts, Fingers, Video, Evaluation, dan Exit. 


$$
\begin{array}{c|l}
\text { Jurnal Sains Komputer dan Teknologi Informasi } & \text { Page } \\
\text { e-issn: 2655-7460. Volume i No.2, Mei 2019 } & 20-26
\end{array}
$$

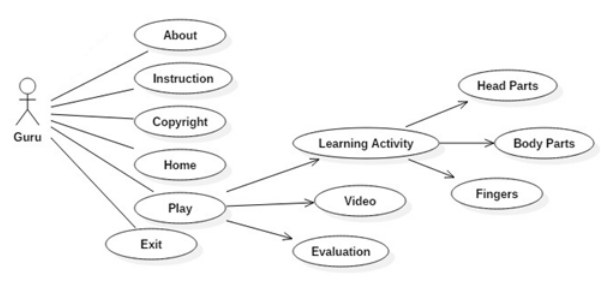

Gambar 1. Use Case Diagram

c. Activity Diagram

\section{Activity Diagram Menu Play}

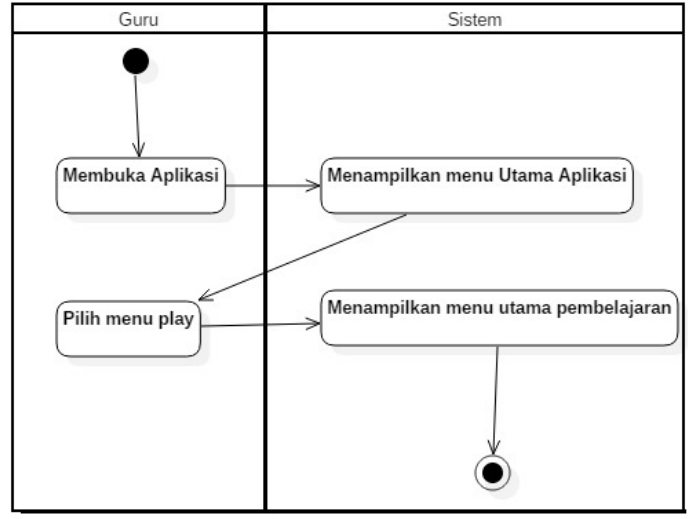

Gambar 2. Activity Diagram Menu Play

Gambar tersebut menjelaskan bahwa terlebih dulu pengguna (pengguna) memulai program, kemudian akan tampil halaman awal. Pada menu awal aplikasi, pengguna memilih tombol Play setelah itu sistem akan menampilkan menu utama pembelajaran. Setelah memilih menu pilihan maka sistem akan menampilkan halaman pembelajaran yang akan dipilih oleh pengguna.

Activity Diagram Menu About

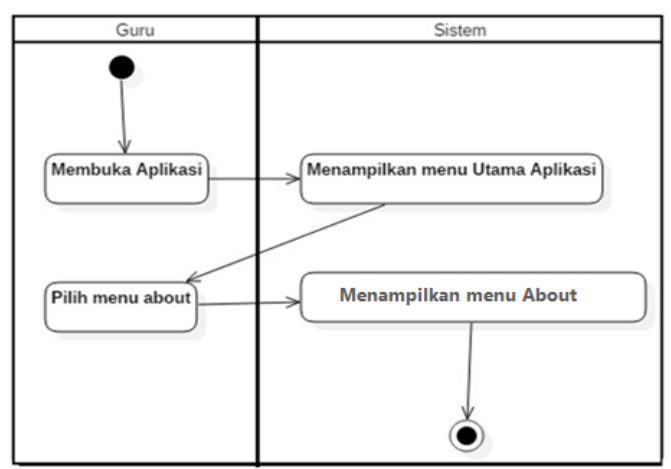

Gambar 3. Activity Diagram Menu About

Gambar tersebut menjelaskan bahwa terlebih dulu pengguna (pengguna) memulai program, kemudian akan tampil halaman awal. Pada menu awal aplikasi, pengguna memilih tombol About, setelah itu sistem akan menampilkan halaman About yaitu penjelasan tentang aplikasi.

\section{Activity Diagram Menu Instruction}

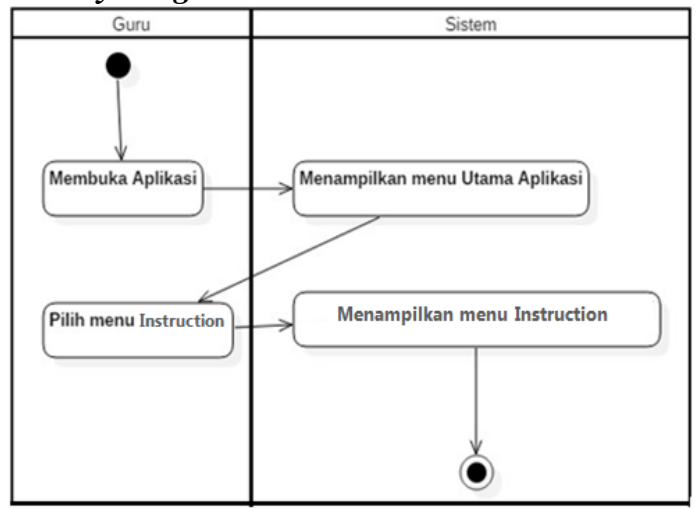

Gambar 4. Activity Diagram Menu Instruction

Gambar tersebut menjelaskan bahwa bahwa terlebih dulu pengguna (pengguna) memulai program, kemudian akan tampil halaman awal. Pada menu awal aplikasi, pengguna memilih tombol Instruction, setelah itu sistem akan menampilkan halaman Instruction yaitu penjelasan tentang instruksi menggunakan aplikasi.

\section{Activity Diagram Menu Copyright}

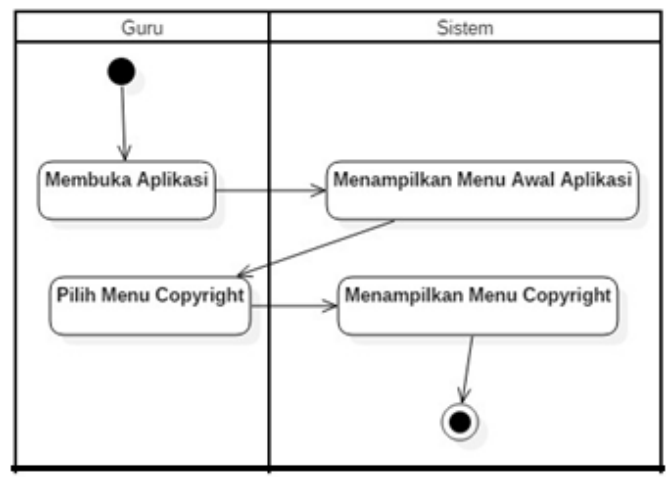

Gambar 5. Activity Diagram Menu Copyright

Gambar tersebut menjelaskan bahwa terlebih dulu pengguna (pengguna) memulai program, kemudian akan tampil halaman awal. Pada menu awal aplikasi, pengguna memilih tombol Copyright, setelah itu sistem akan menampilkan halaman Copyright yaitu Link sumber.

\section{Activity Diagram Menu Home}


Norhayati \& Rosmiati. Implementasi Media Pembelajaran Berbasis Multimedia Untuk

Meningkatkan Minat dan Motivasi Belajar Bahasa Inggris Pada Anak Di Desa Petuk Ketimpun Provinsi Kalimantan Tengah

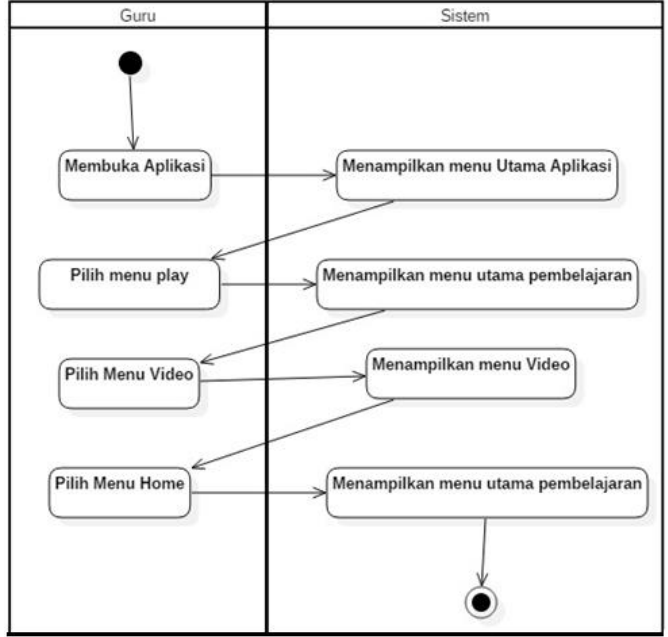

Gambar 6. Activity Diagram Menu Home

Gambar tersebut menjelaskan bahwa terlebih dulu pengguna (pengguna) memulai program, kemudian akan tampil halaman awal. Pada menu awal aplikasi, pengguna memilih tombol Play setelah itu sistem akan menampilkan menu utama pembalajaran. Setelah memilih menu pembelajaran maka sistem akan menampilkan halaman pembelajaran yang akan dipilih oleh pengguna misalnya menu Video, sistem akan menampilkan halaman Video. Didalam menu ini terdapat menu Home yang berfungsi untuk kembali ke menu utama pembelajaran.

\section{Activity Diagram Menu Learning Activity}

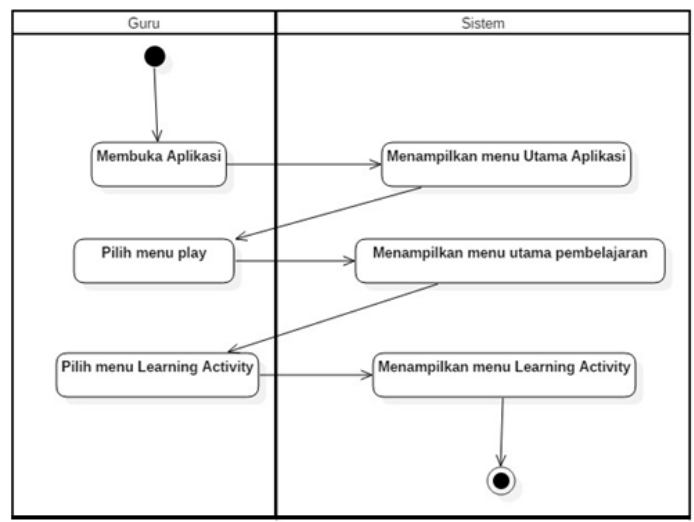

Gambar 7. Activity Diagram Menu Learning Activity

Gambar tersebut menjelaskan bahwa terlebih dulu pengguna (pengguna) memulai program, kemudian akan tampil halaman utama. Pada menu utama aplikasi, pengguna memilih tombol Play setelah itu sistem akan menampilkan menu utama pembalajaran. Setelah itu pilih menu Learning Activity yang berfungsi untuk menampilkan materi pembelajaran.

\section{Activity Diagram Menu Head Parts}

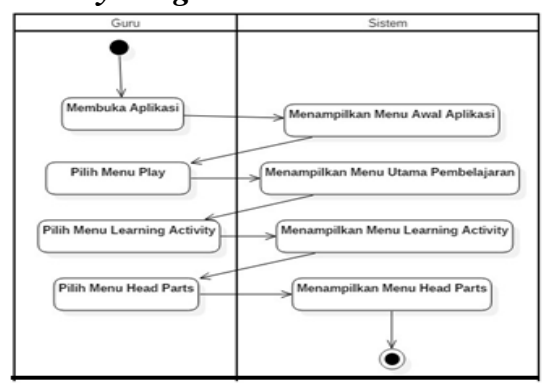

Gambar 8. Activity Diagram Menu Head Parts

Gambar tersebut menjelaskan bahwa terlebih dulu pengguna (pengguna) memulai program, kemudian akan tampil halaman utama. Pada menu utama aplikasi, pengguna memilih tombol Play setelah itu sistem akan menampilkan menu utama pembalajaran. Setelah itu pilih menu Learning Activity yang berfungsi untuk menampilkan materi pembelajaran. Kemudian Klik menu Head Parts maka akan menampilkan menu Head Parts yang berisikan materi pembelajaran bagian kepala.

\section{Activity Diagram Menu Body Parts}

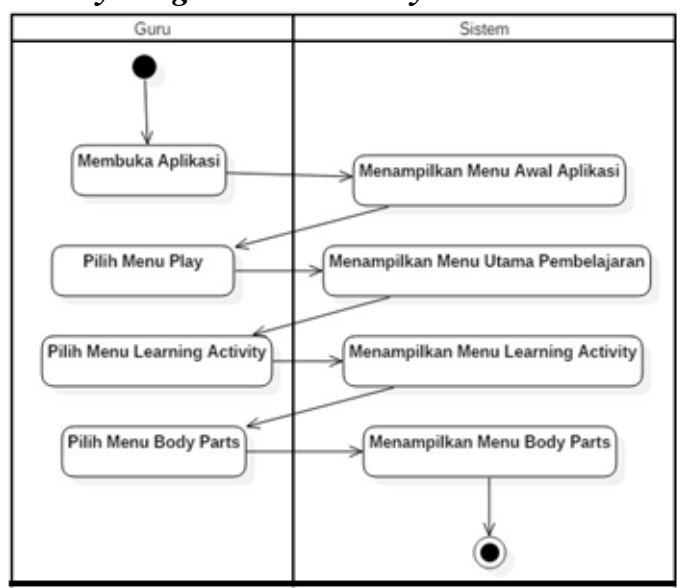

Gambar 9. Activity Diagram Menu Body Parts

Gambar tersebut menjelaskan bahwa terlebih dulu pengguna (pengguna) memulai program, kemudian akan tampil halaman utama. Pada menu utama aplikasi, pengguna memilih tombol Play setelah itu sistem akan menampilkan menu utama pembalajaran. Setelah itu pilih menu Learning Activity yang berfungsi untuk menampilkan materi pembelajaran. Kemudian 


$$
\begin{array}{c|l}
\text { Jurnal Sains Komputer dan Teknologi Informasi } & \text { Page } \\
\text { e-issn: 2655-7460. Volume i No.2, Mei 2019 } & 20-26
\end{array}
$$

Klik menu Body Parts maka akan menampilkan menu Body Parts yang berisikan materi pembelajaran bagian badan.

\section{Activity Diagram Menu Fingers}

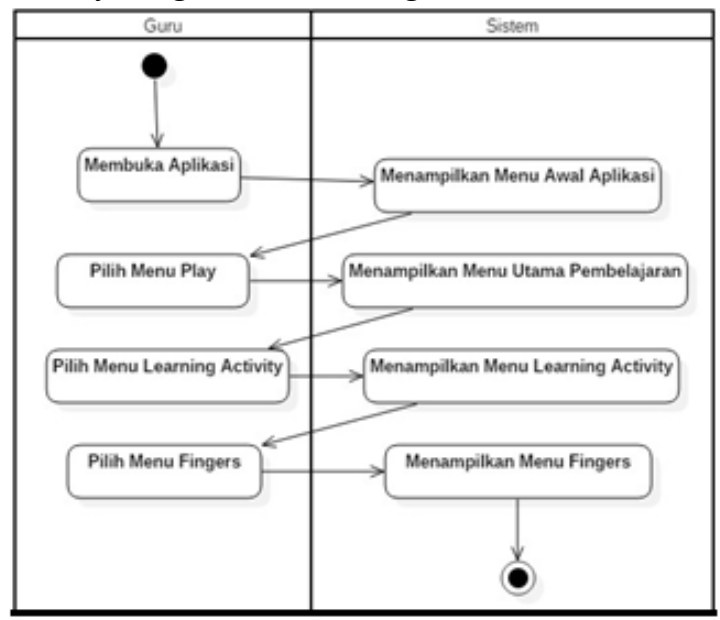

Gambar 10. Activity Diagram Menu Fingers

Gambar tersebut menjelaskan bahwa terlebih dulu pengguna (pengguna) memulai program, kemudian akan tampil halaman utama. Pada menu utama aplikasi, pengguna memilih tombol Play setelah itu sistem akan menampilkan menu utama pembalajaran. Setelah itu pilih menu Learning Activity yang berfungsi untuk menampilkan materi pembelajaran. Kemudian Klik menu Fingers maka akan menampilkan menu Fingers yang berisikan materi pembelajaran bagian jari.

\section{Activity Diagram Menu Video}

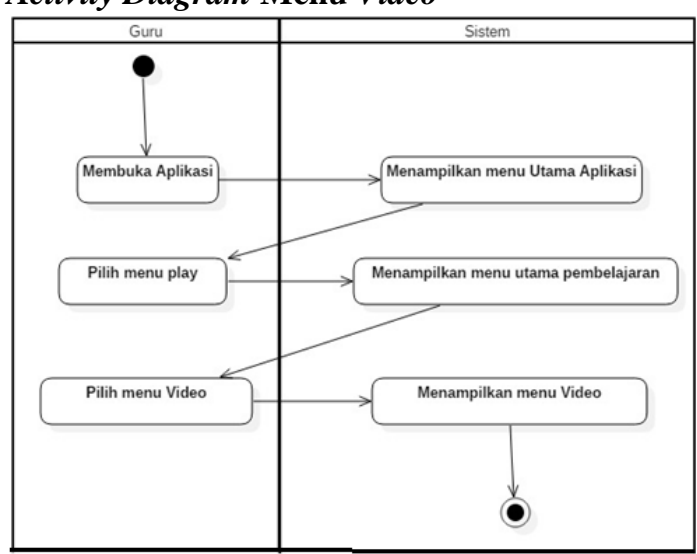

Gambar 11. Activity Diagram Menu Video

Gambar tersebut menjelaskan bahwa terlebih dulu pengguna (pengguna) memulai program, kemudian akan tampil halaman awal. Pada menu awal aplikasi, pengguna memilih tombol Play setelah itu sistem akan menampilkan menu utama pembalajaran. Setelah itu pilih menu Video yang berfungsi untuk menampilkan Video yang berhubungan dengan materi pembelajaran.

\section{Activity Diagram Menu Evaluation}

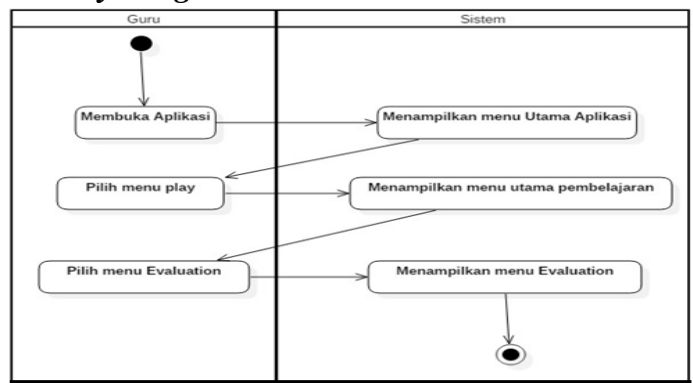

Gambar 12. Activity Diagram Menu Evaluation

Sebelum masuk ke menu Evaluation, terlebih dulu pengguna (pengguna) memulai program, kemudian akan tampil halaman awal. Pada menu awal aplikasi, pengguna memilih tombol Play setelah itu sistem akan menampilkan menu utama pembalajaran. Setelah itu pilih menu Evaluation yang berfungsi untuk menampilkan halaman evaluasi yang berhubungan dengan materi pembelajaran.

\section{Activity Diagram Menu Exit}

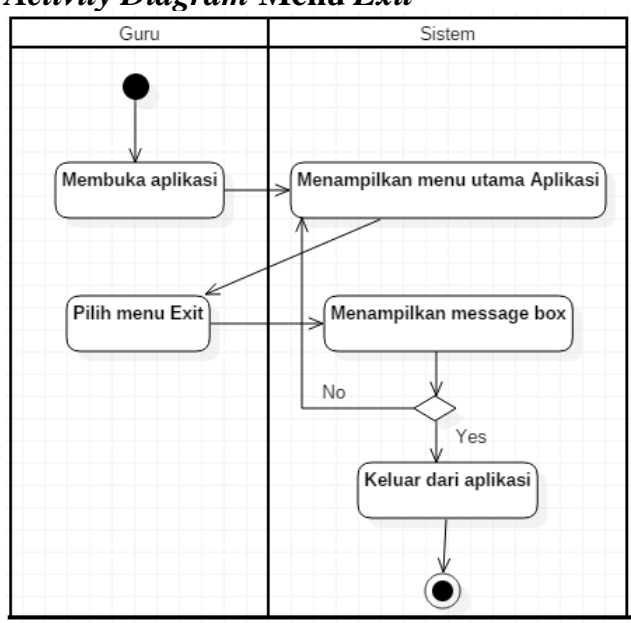

Gambar 13. Activity Diagram Menu Exit

Gambar tersebut menjelaskan bahwa terlebih dulu pengguna (pengguna) memulai program, kemudian akan tampil halaman awal. Pada menu awal aplikasi, pengguna memilih tombol Exit yang berfungsi untuk keluar dari aplikasi.

\section{Penggunaan Media Belajar}


Dalam menjalankan aplikasi "Media pembelajaran bahasa Inggris berbasis multimedia", pengguna harus memiliki file aplikasinya terlebih dahulu, setelah memiliki file aplikasi Media pembelajaran bahasa Inggris berbasis multimedia pada komputer atau laptop, kemudian buka aplikasi dengan klik dua kali pada icon aplikasi. Berikut langkah-langkah dalam menjalankan aplikasi "Media pembelajaran bahasa Inggris berbasis multimedia".

1. Setelah membuka aplikasi, kemudian akan terlihat tampilan halaman menu awal. Tampilan halaman menu awal memuat tombol Play, About, Instruction, Sound On/Off, dan Exit.

2. Jika memilih tombol About maka akan menampilkan informasi tentang aplikasi dan biodata pembuat aplikasi. Jika memilih tombol Instruction maka akan menampilkan cara menggunakan aplikasi, dan jika memilih tombol Exit maka akan keluar dari aplikasi.

3. Pilih tombol Play untuk masuk ke menu utama pembelajaran. Kemudian pilih tombol Learning Activity untuk masuk ke menu materi pembelajaran Head Parts, Body Parts, atau Fingers.

4. Setelah masuk ke menu Learning Activity, jika memilih tombol Head Parts maka akan tampil materi pembelajaran Bahasa Inggris bagian kepala, jika memilih tombol Body Parts maka akan tampil materi pembelajaran Bahasa Inggris bagian badan, dan jika memilih tombol Fingers maka akan tampil materi pembelajaran Bahasa Inggris jari-jari tangan.

5. Kemudian jika memilih tombol Video pada menu utama pembelajaran maka akan tampil video anggota tubuh manusia dalam Bahasa Inggris.

6. Masih di menu utama pembelajaran, jika memilih tombol Evaluation maka akan tampil halaman evaluasi yang bersangkutan dengan materi pelajaran pada Learning Activity.

7. Jika tidak ada aktivitas lain lagi yang ingin dilakukan maka klik tombol Exit, maka akan keluar dari aplikasi.

\section{HASIL DAN PEMBAHASAN}

1. Dalam penelitian ini, telah dibuat dan diimplementasikan sebuah aplikasi yang berfungsi sebagai salah satu bentuk pengembangan kemajuan teknologi yang dapat menjadi sarana media pembelajaran alternatif dalam mata pelajaran Bahasa Inggris yang dapat menambah minat serta motivasi belajar bagi siswa.

2. Aplikasi ini dirancang dengan memadukan audio, video, dan gambar dalam setiap halamannya. Terdapat 3 kategori dalam pembelajaran tersebut yaitu Learning Activity, Video, dan Evaluation. Pada menu Learning Activity terdapat menu Head Parts untuk materi Bahasa Inggris bagian kepala, Body Parts untuk materi bagian badan, dan Fingers untuk materi bagian jari sebagai materi pembelajarannya. Aplikasi ini digunakan secara offline jadi masih bisa dimainkan tanpa adanya internet.

3. Dari pengujian Blackbox seluruh halaman dan button pada aplikasi "Media pembelajaran bahasa Inggris berbasis multimedia" sudah berjalan dengan baik.

\section{Saran}

Untuk mengetahui secara lebih lanjut dan terperinci mengenai kefektifitan dan pengaruh penggunaan media pengajaran terhadap motivasi dan hasil belajar bahasa Inggris maka tim peneliti akan melakukan penelitian lanjutan terkait topik tersebut.

Materi dalam aplikasi media pembelajaran ini pun masih dapat terus dikembangkan dengan menyesuaiakn kebutuhan belajar anak.

\section{Daftar Pustaka}

Ahmadi, Abu dan Widodo Supriyono. 2004. Psikologi Belajar. Cetakan ke-2. Jakarta: Rineka Cipta.

Djaali. 2012. Psikologi pendidikan. Jakarta: Bumi Aksara.

Fathansyah. 2012. Basis Data. Bandung : Informatika Bandung.

Hariana, E., Guardian Yoki Sanjaya, Annisa Ristya Rahmanti, Berti Murtiningsih, dan Eko Nugroho. 2013. Penggunaan Sistem Informasi Manajemen Rumah Sakit (SIMRS) Di DIY. Seminar Nasional 


$$
\begin{array}{c|l}
\text { Jurnal Sains Komputer dan Teknologi Informasi } & \text { Page } \\
\text { e-issn: 2655-7460. Volume i No.2, Mei 2019 } & 20-26
\end{array}
$$

Sistem Informasi Indonesia. Hal. 428-

343

Hurlock, Elizabeth. 2003. Psikologi Perkembangan. Edisi keenam. Jakarta: Erlangga.

Jogiyanto, H. 2010. Analisis dan Desain Sistem Informasi, Edisi IV. Jogyakarta: ANDI

Kendall, K.E. dan Julie, E.K., 2011, Systems Analysis and Design, Prentice Hall, New Jersey

Khodareza \& Komachali, E. (2012). The Effect of Using Vocabulary Flashcard on Iranian on Iranian Pre-University Students' Vocabulary Knowledge. Canadian Center of Science and Education Journal, 5 (3): 134-147.

Mahedy, K. (2012). Implementasi Media Pembelajaran Berbasis multimedia Informasi Dan Komunikasi Untuk Meningkatkan Minat Dan Motivasi Belajar Ipa Mahaanak Jurusan Pendidikan Dasar Program Pascasarjana Universitas Pendidikan Ganesha. Prosiding APTEKINDO, 6(1). Retrieved from https://ejournal.undiksha.ac.id/inde x.php/APTEKINDO/article/view/70/64

Purwanto, M. Ngalim. 1988. Psikologi Pendidikan. Bandung: Remadja Karya $\mathrm{CV}$

Ramdhani, M. T. 2018. Manajemen Pengembangan Kurikulum 2013 Berbasis Komputer di SMPN 6 Palangka Raya. Jurnal Sains Komputer dan Teknologi Informasi. Vol 1 Issue 1 e-ISSN 26557460 . https://doi.org/10.33084/jsakti.v1i1.453

Sardiman, A.M. 2000. Interaksi dan Motivasi Belajar Mengajar. Jakarta Grafindo Persada.

Sitompul, E. (2014). Teaching Vocabulary Using Flashcards and Word List. Journal of English and Education, 1(1), 52-58. Retrieved from http://ejournal.upi.edu/index.php/LE/article/view/325/214

Slameto. 2003. Belajar dan Faktor-faktor yang Mempengaruhinya. Jakarta: PT. Rineka Cipta.

Santoso, Insap. 2009. Interaksi Manusia dan Komputer. Yogyakarta : Andi Offset

Winkel. 2004. Psikologi pendidikan dan evaluasi belajar, Jakarta: Gramedia 